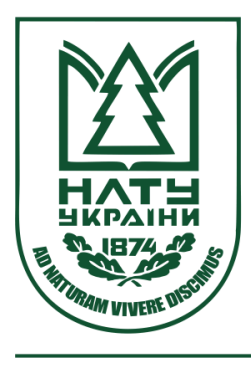

Науковий вісник НлтУ України Scientific Bulletin of UNFU

https://nv.nltu.edu.ua

https://doi.org/10.36930/40310409

ISSN 2519-2477 (online)

Article received 02.08.2021 p.

Article accepted 09.09.2021 p.

A. A. Dzyba

UDC 502.75 (581.93)

orhideya_oncydium@ukr.net

А. А. Дзиба

Національний університет біоресурсів і природокористування України, м. Київ, Україна

\title{
СИСТЕМАТИЧНА, БІОМОРФОЛОГІЧНА ТА ЕКОЛОГІЧНА СТРУКТУРИ СУЧАСНОЇ ДЕНДРОФЛОРИ КОМПЛЕКСНИХ ПАМ'ЯТОК ПРИРОДИ 1960-ИХ РОКІВ УКРАЇНСЬКОГО ПОЛІССЯ
}

\begin{abstract}
На Українському Поліссі у 60-х роках ХХ ст. у північній частині Рівненської області було створено п'ять комплексних пам'яток природи (КПП) місцевого значення. Наведено результати інвентаризації дендрофлори у КПП "Трипутнянський парк", "Рокитнівський дендропарк", "Сарненський дендропарк", "Висоцький дендропарк"; "Більський дендропарк". Встановлено, що систематична структура у п'яти КПП представлена 157 видами, 5 гібридами, одним різновидом, що належать до 82 родів, 32 родин. Найбільше дендрорізноманіття представлено у двох КПП "Рокитнівський дендропарк" i "Сарненський дендропарк", відповідно 117 і 77 видів деревних рослин, що належать до 68 і 47 родів, 29 і 21 родин. У п'яти КПП 70,3 \% видів деревних рослин належать до шести категорій раритетності ЧС MCOП, найбільше представників категорій LC та DD. У двох КПП "Сарненський дендропарк" та "Висоцький дендропарк" росте Fraxinus pennsylvanica Marsh., який перебуває під критичною загрозою зникнення, що належить до категорії CR. Здійснивши розподіл видів за висотою, з'ясовано, що переважають листяні дерева першої та четвертої величин, що відповідно становить 33 і 27 видів, чагарники високі та середні представлені однаковою кількістю - по 24 види. Серед хвойних видів переважають дерева першої величини 20 видів. 155 видів деревних рослин належать до фанерофітів, мега-, мезо- та мікрофанерефіти представлені майже однаковою кількістю, що відповідно становить 40, 49 та 44 види, з яких переважають листопадні дерева. Найбільшого поширення набули мезофіти - 40,5 \% від загальної кількості видів, майже однаковою кількістю представлені такі групи: мезогігрофіти та ксеромезофіти (відповідно 17,1 та 19,0\%). За вимогливістю до освітлення - поширення набули представники геміоскіофітів (72 види) та геліофітів (63 види). За вибагливістю до трофності грунту на території КПП переважають мезотрофи 88 видів $(55,7 \%)$, дещо менше оліготрофів - 42 види $(26,6 \%), 26$ видів $(16,5 \%)$ належить до мегатрофів. Для з'ясування кореляційних зв'язків між досліджуваними флорами п'яти КПП обчислено коефіцієнт подібності Серенсена-Чекановського, максимальні значення якого отримані для двох пар дендрофлор КПП "Рокитнівський дендропарк" і "Сарненський дендропарк"; КПП "Сарненський дендропарк" і "Більський дендропарк", що свідчить про значний рівень подібності дендрофлор.

Ключові слова: раритетні; види деревних рослин; подібність; репрезентативність; парк.
\end{abstract}

\section{Вступ / Introduction}

Пріоритетами охорони навколишнього природного середовища і раціонального використання природних ресурсів $є$ збереження біологічного і ландшафтного різноманіття, збереження і розширення територій з природним ландшафтом, посилення природоохоронної діяльності на заповідних і рекреаційних територіях [18]. Значну увагу приділяють екологічній культурі і свідомості, інформованості людей про екологічну ситуацію у світі, регіоні, на місці проживання, їх обізнаності 3 можливими шляхами вирішення різних екологічних проблем, з концептуальними підходами до збереження, цінного ставлення до природи як джерела задоволення естетичних, комунікативних, пізнавальних, рекреаційних потреб особистості [17]. Лісові екосистеми природно-заповідного фонду є осередком збереження біорізноманіття Полісся України і потребують уваги до вивчення їх сучасного стану [16]. Автохтонні та інтродуковані дендрораритети, що використовуються у насадженнях різного призначення, розширюють можливості для створення колекцій ex situ, для збереження рослин, які перебувають під загрозою зникнення. Багато таксонів, що перебувають під загрозою, вже використовують в озелененні, однак існує великий невикористаний потенціал - для досягнення достатньо високого рівня представленості генетичного різноманіття та рослинних матеріалів для програм реінтродукції та відновлення. Озеленення міст і селищ є невід'ємною частиною стратегії збереження ex situ та може забезпечити необхідний додатковий простір для створення відповідних колекцій [3]. Території об'єктів природно-заповідного фонду є привабливим осередком для зеленого туризму та мають значний рекреаційний потенціал [8].

Об'єкт дослідження - сучасна дендрофлора комплексних пам'яток природи (КПП) 60-х років XX ст. Українського Полісся.

Предмет дослідження - систематична, біоморфоло-

\section{Інформація про автора:}

Дзиба Анжела Андріївна, канд. с.-г. наук, доцент, кафедра ландшафтної архітектури та фітодизайну. Email: orhideya_oncydium@ukr.net; https://orcid.org/0000-0003-4422-288X

Цитування за ДСту: Дзиба А. А. Систематична, біоморфологічна та екологічна структури сучасної дендрофлори комплексних пам'яток природи 1960-их років Українського Полісся. Науковий вісник НлтУ України. 2021, т. 31, № 4. С. 59-64.

Citation APA: Dzyba, A. A. (2021). Systematic, biomorphological and ecological structures of current denroflora of complex natural monuments of the 1960s of Ukrainian Polissya. Scientific Bulletin of UNFU, 31(4), 59-64. https://doi.org/10.36930/40310409 
гічна, екологічна структури сучасної дендрофлори КПП 60-х років XX ст. Українського Полісся.

Мета роботи - систематизувати дендрофлору п'яти КПП 60-х років ХХ ст. Українського Полісся за біоморфологічними, екологічними ознаками, виокремити дендрораритети на основі здійсненої інвентаризації.

Для досягнення зазначеної мети визначено такі основні завдання дослідження: провести інвентаризацію дендрофлори п'яти КПП; встановити систематичну, біморфологічну та екологічну структури; виокремити дендрораритети; проаналізувати подібність дендрофлор.

Наукова новизна отриманих результатів дослідження - вперше для п'яти КПП Українського Полісся визначено подібність дендрофлор за допомогою коефіцієнта подібності Серенсена-Чекановського та побудовано комбіновану матрицю подібності.

Практична значущість результатів дослідження виявлення дендрораритетів у КПП дасть змогу виокремити найбільш рідкісні, що належать до категорій NT, VU, EN, CR та цінні серед них і залежно від цього проводити подальше збереження або розмноження для впровадження в озеленення або створення нових колекцій у парках.

Аналіз останніх досліджень та публікацій. За останнє десятиліття досліджують дендрофлору різних регіонів України у насадженнях різного призначення. За цей час вивчено дендрофлору байрачного лісу балки Широка, встановлено видовий склад, виокремлено автохтонні та інтродуковані види деревних рослин, з'ясовано породний склад верхніх ярусів деревостану та підліску, виявлено види 3 високою інвазійною здатністю [21]. Проведено флористичний та популяційний аналізи автохтонних заповідних дендросозофітів Українського Полісся [14]. Проаналізовано екологічну і географічну структуру дендрофлори штучних заповідних парків Рівненської області [11]. Встановлено таксономічний склад, біоморфологічну та морфологічну структури арборетуму Шацького лісового коледжу ім. В. В. Сулька [2]. Здійснено аутфітосозологічне оцінювання дендроекзотів відділу Pinophyta ботанічного саду Чернівецького Національного університету імені Юрія Федьковича [10].

Матеріали та методи досліджень. Застосовано системний підхід та порівняльний аналіз отриманого фактичного матеріалу; інвентаризацію видів деревних рослин проводили маршрутним методом [15], уточнювали вид деревних рослин за працями $[5,6,22]$. Видову назву - відповідно до міжнародної класифікації Word Flora Online (2021) [20], класифікацію життєвих форм за Raunkiaer (1934) [13], розподіл видів деревних рослин за висотами - за Kalinichenko (2003) [5]. Види деревних рослин перевіряли на належність їх до Червоного Списку Міжнародного Союзу Охорони Природи (ЧС МСОП) [4]. Згідно з вимогами до основних чинників середовища аналізували належність деревних рослин до різних екологічних груп. Для порівняння подібності дендрофлор п'яти КПП застосовували коефіцієнт Серенсена-Чекановського [9], який розраховують за формулою $C_{s c}=2 c /(a+b)$, де: $a$ - кількість видів в одному об'єкті; $b$ - кількість видів у другому об'єкті; $c$ - кількість спільних видів для першого та другого об'єктів. Він показує відношення числа видів, виявлених в обох об'єктах одночасно, до середнього числа видів у цих об'єктах. Бінарні коефіцієнти розраховують на основі однакових отриманих даних, і приймають значення від $0\left(C_{j}=0\right.$, якщо види деревних рослин абсолютно відмінні) до 1 ( $C_{j}=1$, дендрофлора тотожна), за коефіцієнта $C_{j} \geq 0,5$ - дендрофлору вважають подібною $C_{s c}$.

\section{Результати дослідження та їх обговорення / Research results and their discussion}

На Українському Поліссі у 60-х роках ХХ ст. було створено п'ять КПП ("Трипутнянський парк"; "Рокитнівський дендропарк"; "Сарненський дендропарк"; "Висоцький дендропарк"; "Більський дендропарк") місцевого значення, які зосереджені у північній частині Рівненської області [1]. Метою створення КПП було вивчення рідкісних дендроекзотів, збереження колекції цінних видів деревних рослин, а також подальшого їхнього впровадження у лісові насадження та в озеленення селищ; збереження старовинного парку. Нині на території п'яти КПП ростуть 158 видів, 5 гібридів, один різновид деревних рослин, що належать до 82 родів, 32 родин, поширені представники відділу Magnoliophyta (29 родин, 70 родів, 130 видів, 5 гібридів, один різновид) (табл. 1). Серед листяних видів деревних рослин значна кількість видів належить до родини Rosaceae Juss. 26,0 \%, серед хвойних - до родини Pinaceae Lindl. 10,8 \%. Родини Taxaceae S. F. Gra., Rhamnaceae R. Br., ElaeagnaceaeLindl. Ulmaceae Mirb., Moraceae Lindl., Cannabaceae Martinov., Anacardiaceae Lindl., Rutaceae Juss., Platanaceae Lindl., Buxaceae Dumort., Vitaceae Lindl., Aquifoliaceae de Candolle ex Richard., Bignoniaceae Juss. представлені одним-двома видами деревних рослин, що належать переважно до одного роду. Вісім родин мають трьох-чотирьох представників, належать до 17 родів (16,4\%). Значну кількість видів від 7 до 10 (30,3 \%), мають шість родин, причому кількість родів коливається від двох (Salicaceae Mirb., Sapindaceae Juss.) до шести (Cupresaceae Rich. Ex Bartl.). Родина Malvaceae Juss. представлена 5 видами 2 родами (див. табл. 1).

Табл. 1. Систематична структура деревних рослин у КПП 60-х років XX ст. Українського Полісся / Systematic structure of woody plants in CNMs of the 1960 s of Ukrainian Polissya

\begin{tabular}{|c|c|c|c|c|c|c|}
\hline \multirow{2}{*}{ Родина } & \multicolumn{2}{|c|}{ Рід } & \multicolumn{2}{|c|}{ Вид } & \multicolumn{2}{|c|}{$\begin{array}{l}\text { Гібрид / } \\
\text { різновид }\end{array}$} \\
\cline { 2 - 8 } & $\begin{array}{c}\text { кіль- } \\
\text { кість }\end{array}$ & $\%$ & $\begin{array}{l}\text { кіль- } \\
\text { кість }\end{array}$ & $\%$ & $\begin{array}{l}\text { кіль- } \\
\text { кість }\end{array}$ & $\%$ \\
\hline Cupresaceae Rich. Ex Bartl. & 6 & 7,3 & 10 & 6,3 & - & - \\
\hline Pinaceae Lindl. & 5 & 6,2 & 17 & 10,8 & - & - \\
\hline Taxaceae S. F. Gra. & 1 & 1,2 & 1 & 0,6 & - & - \\
\hline Fabaceae Lindl. & 4 & 5,0 & 4 & 2,5 & - & - \\
\hline Berberidaceae Torr. et Gray. & 1 & 1,2 & 3 & 1,9 & - & - \\
\hline Fagaceae A. B. R. & 3 & 3,7 & 8 & 5,1 & - & - \\
\hline Juglandaceae A. Rich. ex Kunt. & 1 & 1,2 & 4 & 2,5 & - & - \\
\hline Betulaceae S. F. Gray & 4 & 5,0 & 7 & 4,4 & - & - \\
\hline Oleaceae Lindl. & 4 & 5,0 & 7 & 4,4 & - & - \\
\hline Celastraceae Lindl. & 2 & 2,4 & 3 & 1,9 & - & - \\
\hline Caprifoliaceae Vent. & 3 & 3,7 & 3 & 1,9 & - & - \\
\hline Adoxaceae E. Mey. & 2 & 2,4 & 2 & 1,3 & - & - \\
\hline Cornaceae Link & 1 & 1,2 & 2 & 1,3 & - & - \\
\hline Hydrangeaceae Dumort. & 3 & 3,7 & 3 & 1,9 & - & - \\
\hline
\end{tabular}

Scientific Bulletin of UNFU, 2021, vol. 31, no 4 


\begin{tabular}{|c|c|c|c|c|c|c|}
\hline Grossulariaceae DC & 1 & 1,2 & 3 & 1,9 & - & - \\
\hline Rosaceae Juss. & 19 & 23,2 & 41 & 26,0 & $2 /-$ & $40,0 /-$ \\
\hline Rhamnaceae R. Br. & 1 & 1,2 & 1 & 0,6 & - & - \\
\hline ElaeagnaceaeLindl. & 1 & 1,2 & 1 & 0,6 & - & - \\
\hline Ulmaceae Mirb. & 1 & 1,2 & 2 & 1,3 & - & - \\
\hline Moraceae Lindl. & 1 & 1,2 & 1 & 0,6 & - & - \\
\hline Cannabaceae Martinov. & 1 & 1,2 & 1 & 0,6 & - & - \\
\hline Salicaceae Mirb. & 2 & 2,4 & 7 & 4,4 & $-/ 1$ & $-/ 100$ \\
\hline Sapindaceae Juss. & 2 & 2,4 & 9 & 5,7 & $1 /-$ & $20,0 /-$ \\
\hline Anacardiaceae Lindl. & 1 & 1,2 & 1 & 0,6 & - & - \\
\hline Rutaceae Juss. & 2 & 2,4 & 2 & 1,3 & - & - \\
\hline Malvaceae Juss. & 2 & 2,4 & 5 & 3,2 & - & - \\
\hline Platanaceae Lindl. & 1 & 1,2 & 1 & 0,6 & - & - \\
\hline Buxaceae Dumort. & 1 & 1,2 & 1 & 0,6 & - & - \\
\hline Vitaceae Lindl. & 2 & 2,4 & 2 & 1,3 & - & - \\
\hline Magnoliaceae Juss. & 2 & 2,4 & 3 & 1,9 & $2 /-$ & $40,0 /-$ \\
\hline $\begin{array}{c}\text { Aquifoliaceae de Candol- } \\
\text { le ex Richard. }\end{array}$ & 1 & 1,2 & 1 & 0,6 & - & - \\
\hline Bignoniaceae Juss. & 1 & 1,2 & 2 & 1,3 & - & - \\
\hline Pazom & 82 & 100 & 158 & 100 & $5 / 1$ & $100 / 100$ \\
\hline
\end{tabular}

Найбільше дендрорізноманіття представлено у двох КПП "Рокитнівський дендропарк" і "Сарненський дендропарк", відповідно 117 і 77 видів деревних рослин, що належать до 68 і 47 родів, 29 і 21 родин (табл. 2). У КПП "Рокитнівський дендропарк" росте 74,5 \% рослин, що виявлені на території п'яти КПП. Майже однакова кількість видів зростає у двох КПП "Висоцький дендропарк" та "Більський дендропарк", 58 та 55 відповідно. Найменше видів (36) виявлено у КПП "Трипутнянський парк, проте 69 \% із них перебувають під охороною ЧС МСОП.

У п'яти КПП 70,3 \% видів деревних рослин належать до шести категорій раритетності ЧС МСОП, найбільше представників категорій LC (під невеликою загрозою) та DD (після збирання інформації вони можуть бути віднесені до якоїсь загрози або ризику) (рис. 1).

Тільки у двох КПП "Сарненський дендропарк" та "Висоцький дендропарк" зростає Fraxinus pennsylvanica Marsh., який перебуває під критичною загрозою зникнення, що належить до категорії CR. Fraxinus excelsior L. має категорію NT (близький до загрозливого стану) представлений на території п'яти КПП, водночас у КПП ("Сарненський дендропарк") росте ще три види, що належать до категорії NT, а саме: Platycladus orientalis (L.) Franco., Cryptomeria japonica (Thunb. ex L.f.) D. Don., Abies holophylla Maxim., у КПП "Рокитнівський дендропарк" - Chamaecyparis lawsoniana (A. Murra bis) Parl. Чотири види перебувають під загрозою зникнення (категорія EN): Metasequoia glyptostroboides $\mathrm{Hu}$ and W. C. Cheng. та Armeniaca vulgaris Lam. зростють тільки у КПП "Рокитнівський дендропарк", Malus niedzwetzkyana Dieck ex Koehne. (КПП "Висоцький дендропарк"), Juglans cinerea L. виявлено у трьох КПП ("Сарненський дендропарк", "Рокитнівський дендропарк" та "Висоцький дендропарк"). До категорії вразливих належить Aesculus hippocastanum L. - росте у чотирьох КПП ("Сарненський дендропарк", "Рокитнівський дендропарк", Трипутнянський парк", "Висоцький дендропарк").

Табл. 2. Репрезентативність дендрофлори у КПП 60-х років XX ст. Українського Полісся / Representativeness of dendroflora in CNMs of the 1960s of Ukrainian Polissya

\begin{tabular}{|c|c|c|c|c|c|c|c|c|}
\hline \multirow{2}{*}{ КПП } & \multicolumn{2}{|c|}{ Родина } & \multicolumn{2}{|c|}{ Рід } & \multicolumn{3}{c|}{ Вид } & \multicolumn{2}{c|}{ Гібрид / різновид } \\
\cline { 2 - 9 } & кількість & $\%$ & кількість & $\%$ & кількість & $\%$ & кількість & $\%$ \\
\hline Трипутнянський парк & 16 & 50,0 & 31 & 37,8 & 36 & 22,9 & - & - \\
\hline Рокитнівський дендропарк & 29 & 90,6 & 68 & 82,9 & 117 & 74,5 & $2 /-$ & $40,0 /-$ \\
\hline Сарненський дендропарк & 21 & 65,6 & 47 & 57,3 & 77 & 49,0 & $2 / 1$ & $40,0 / 100$ \\
\hline Висоцький дендропарк & 20 & 62,5 & 40 & 48,7 & 58 & 36,9 & $3 / 1$ & $60,0 / 100$ \\
\hline Більський дендропарк & 20 & 62,5 & 40 & 48,7 & 55 & 35,0 & - & - \\
\hline
\end{tabular}

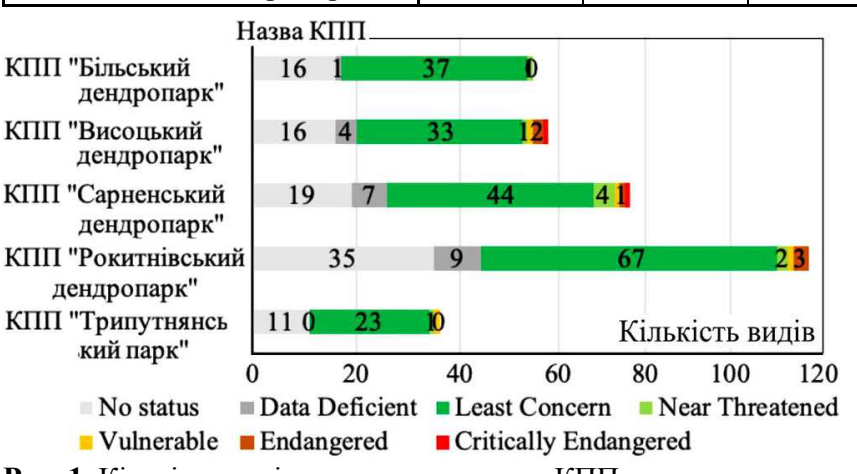

Рис. 1. Кількість видів деревних рослин у КПП, занесених до ЧС МСОП / Number of woody plants species in CNMs, listed in the IUCN Red List

Здійснивши розподіл видів за висотою, з'ясовано, що переважають листяні дерева першої величини (>25 м), дерева четвертої величини (5(7)-15 м), що відповідно становить 33 і 27 видів, чагарники високі (2,55,0 м) та середні (1,0-2,5 м) представлені однаковою кількістю - по 24 види. Серед хвойних видів переважають дерева першої величини (>25 м), що становить 20 видів, до дерев другої, третьої та четвертої величин належать по два види (Pinus banksiana Lamb., Pinus cembra L., Platycladus orientalis (L.) Franco., Taxus bac- cata L., Juniperus communis L., Juniperus squamata Buch. Ham.) та по одному виду - до високих та середніх чагарників (Pinus mugo Turra., Juniperus sabina L.) (рис. 2).

Кількість видів

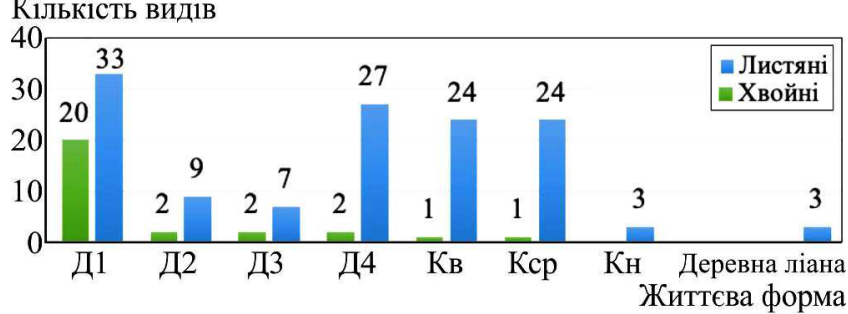

Рис. 2. Розподіл дерев та чагарників за висотою: Д - дерево; $K$ кущ; Д1 -> 25 м; Д2-20-25 м; Д3-15-20 м; Д4-5(7)-15 м; Кв $-2,5-5 \mathrm{~m} ; K c p-1-2,5 ; K H-0,5-1 \mathrm{~m} /$ Distribution of trees and shrubs by height: $D$ - wood; $K$ - shrub; $D 1->25 \mathrm{~m} ; D 2-20$ $25 \mathrm{~m} ; D 3-15-20 \mathrm{~m} ; D 4-5$ (7) - $15 \mathrm{~m} ; S_{\text {high }}-2.5-5 \mathrm{~m} ; S_{\text {medium }}-1$ $\left.2.5 ; K_{\text {low }}-0.5-1 \mathrm{~m}\right)$

Згідно 3 класифікацією життєвих форм Раункієра, 155 видів деревних рослин належать до фанерофітів, мега-, мезо- та мікрофанерефіти представлені майже однаковою кількістю, що відповідно становить 40, 49 та 44 види, з яких переважають листопадні дерева. На території КПП росте також три види хамефітів (рис. 3). 
Кількість видів

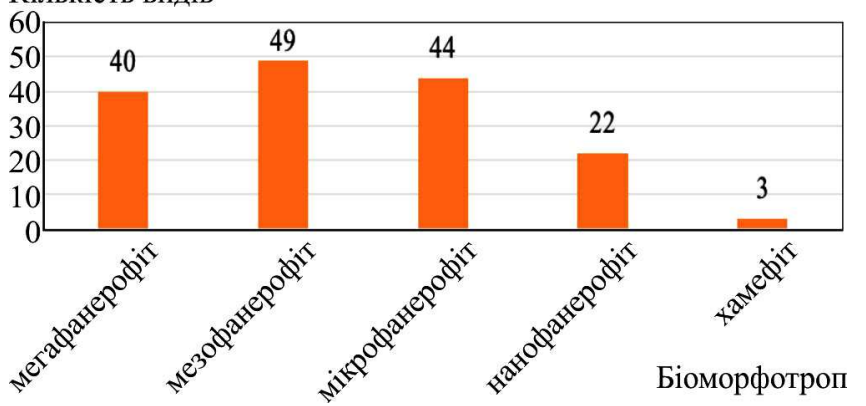

Рис. 3. Біоморфний спектр дендрофлори / Biomorphic spectrum of dendroflora

Проаналізовано дендрофлору КПП за такими показниками, як: вимогливість до грунтової вологи, освітлення, родючості грунту. Виявлено, що найбільшого поширення набули мезофіти - 64 види (40,5 \% від загальної кількості видів), майже однаковою кількістю представлені такі групи: мезогігрофіти та ксеромезофіти (відповідно 27 та 30 видів, 17,1 та 19,0\%), гігрофіти та ксерофіти (12 та 17 видів, 7,6 та 10,8\%), мало поширені гігромезофіти та мезоксерофіти (3 та 5 видів, 1,9 та 3,2\%) (рис. 4). Найбільш цінною є група ксерофітів, які за сучасних умов можуть бути перспективними для подальшого впровадження у різні типи насаджень, зокрема: Platycladus orientalis (L.) Franco., Juniperus squamata Buch. Ham., Pseudotsuga menziesii (Mirb.) Franco., Berberis vulgaris L., Berberis thunbergii DC., Quercus pubescens Willd. та інші.

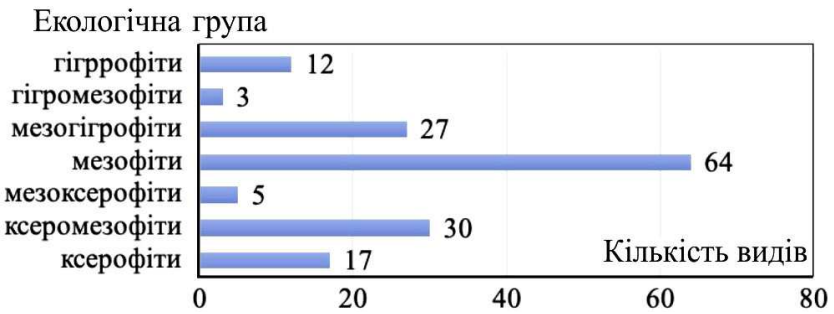

Рис. 4. Екологічна структура видів деревних рослин (вологість) / Ecological structure of woody plant species (humidity)

Аналіз за вимогливістю до освітлення показав, що поширення набули представники геміоскіофітів 72 види та геліофітів 63 види. Значно менше скіофітів, всього 23 види (Thuja plicata Donn ex D. Don., Cryptomeria japonica (Thunb. ex L.f.) D. Don., Abies alba Mill., Pinus strobus L., Corylus avellana L., Sambucus nigra L. та інші) (рис. 5).

Екологічна група

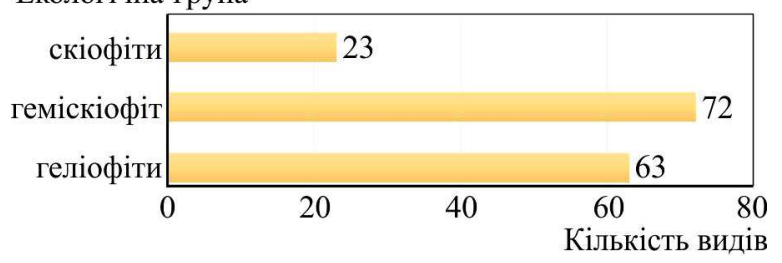

Рис. 5. Екологічна структура видів деревних рослин (світло) /

Ecological structure of woody plant species (light)

За вибагливістю до трофності грунту на території КПП переважають мезотрофи 88 видів (55,7\%), дещо менше оліготрофів - 42 види (26,6 \%), 26 видів (16,5\%) належить до мегатрофів (Cryptomeria japonica (Thunb. ex L.f.) D. Don., Thuja plicata Donn ex D. Don., Picea obovata Ledeb., Abies holophylla Maxim., Quercus petraea (Matt.) Liebl., Juglans regia L., Corylus colurna L., Plata- nus orientalis L. та інші), Acer tataricum L., Acer negundo L. - належать до мезооліготофів (рис. 6).

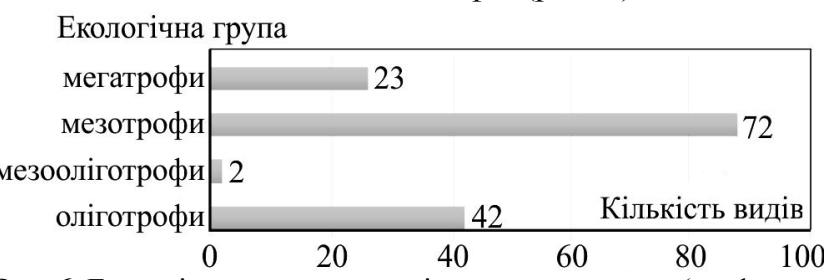

Рис. 6. Екологічна структура видів деревних рослин (троф-

ність) / Ecological structure of woody plant species (trophic)

Для візуалізації кореляційних зв'язків між досліджуваними флорами п'яти КПП ми застосували матрицю перетину-подібності. За результатами аналізу, значення коефіцієнта подібності Серенсена-Чекановського становить в межах $0,36 \leq C_{s c} \geq 0,59$, середнє значення, що свідчить про подібність дендрофлори. Максимальні значення коефіцієнта Серенсена-Чекановського маємо для двох пар дендрофлор: $A$ - КПП "Рокитнівський дендропарк" і $B$ - КПП "Сарненський дендропарк"; $B$ КПП "Сарненський дендропарк" і $D$ - КПП "Більський дендропарк" ( $\left.C_{s c}=0,59\right)$ (табл. 3). За незначної кількості інродукованих видів у колекції $C_{s c} \leq 0,50$, що вплинуло на невелику кількість спільних видів.

Табл. 3. Комбінована матриця перетину-подібності дендрофлор п'яти КПП 60-х років ХХ ст. Українського Полісcя / Combined matrix of cross-similarity of dendroflora of five CNMs of the1960s of Ukrainian Polissya

\begin{tabular}{|c|c|c|c|c|c|c|}
\hline \multicolumn{2}{|c|}{} & $\boldsymbol{A}$ & $\boldsymbol{B}$ & $\boldsymbol{C}$ & $\boldsymbol{D}$ & $\boldsymbol{E}$ \\
\cline { 3 - 7 } & & $\mathbf{1 1 7}$ & $\mathbf{7 7}$ & $\mathbf{5 8}$ & $\mathbf{5 5}$ & $\mathbf{3 6}$ \\
\hline $\boldsymbol{A}$ & $\mathbf{1 1 7}$ & - & 0,59 & 0,47 & 0,5 & 0,41 \\
\hline $\boldsymbol{B}$ & $\mathbf{7 7}$ & 57 & - & 0,55 & 0,59 & 0,46 \\
\hline $\boldsymbol{C}$ & $\mathbf{5 8}$ & 41 & 37 & - & 0,44 & 0,36 \\
\hline $\boldsymbol{D}$ & $\mathbf{5 5}$ & 43 & 39 & 25 & - & 0,53 \\
\hline $\boldsymbol{E}$ & $\mathbf{3 6}$ & 31 & 26 & 17 & 24 & - \\
\hline
\end{tabular}

Примітка: $A$ - КПП "Рокитнівський дендропарк"; $B-$ КПП "Сарненський дендропарк"; $C$ - КПП "Висоцький дендропарк"; $D$ - КПП "Більський дендропарк"; $E$ - КПП "Трипутнянський парк", $A, B, C, B$ - об'єкти, що порівнюються, цифри - кількість видів у КПП; на сірому фоні абсолютна кількість спільних видів для всіх пар об'єктів, на білому фоні - значення коефіцієнта Серенсена-Чекановського.

Десять видів: Thuja occidentalis L., Picea abies Karst., Robinia pseudoacacia L., Quercus robur L., Carpinus betulus L., Syringa vulgaris L., Fraxinus excelsior L., Frangula alnus Mill., Acer platanoides L., Tilia cordata Mill. $€$ спільними для всіх КПП.

Обговорення результатів дослідження. На Українському Поліссі дендрофлора у п'яти КПП представлена 158 видами деревних рослин, серед яких 111 дендрораритети, найчисельніший відділ Magnoliophyta (82,3 \%). Як зазначає [12], дендросозофлора природно-заповідних територій Українського Полісся нараховує 105 видів деревних рослин, серед яких переважають представники відділу Pinophyta (59,0 \%).

Екологічна структура дендрофлори за ступенем вимогливості рослин до умов зволоження п'яти КПП представлена сімома групами, де переважають мезофіти (64,0 \%), (див. рис. 4). В екологічній структурі дендросозофлори Українського Полісся, за ступенем вимогливості рослин до умов зволоження переважають три основні групи: ксерофіти, мезофіти, гігрофіти, пе- 
реважають види групи мезофітів (41,0 \%) [12]. За відношенням до освітлення серед раритетних видів переважають геліофіти (45,7\%) [12]. Проте у п'яти КПП найчисельніша група - геміскіофіти (72,0 \%), геліофітів дещо менше (63,0 \%) (див. рис. 5). В екологічній структурі видів деревних рослин за трофністю грунту переважають мезотрофи як серед дендрофлори п'яти КПП, так i серед дендросозофлори заповідних територій Українського Полісся.

На основі опису локальних дендрофлор з використанням коефіцієнтів подібності можна отримати приблизну картину районування досліджуваної території [7]. Природно-кліматичні чинники відіграють велику роль у формуванні відмінностей таксономічної структури урбанофлор. Спектри життєвих форм у різних природно-кліматичних умовах схожі [19]. Значний рівень подібності дендрофлор отримано на основі коефіцієнта подібності Серенсена-Чекановського у КПП "Рокитнівський дендропарк" i "Сарненський дендропарк"; КПП "Сарненський дендропарк" і "Більський дендропарк".

\section{Висновки / Conclusions}

Дендрофлора п'яти КПП нараховує 158 видів, 5 гібридів, один різновид деревних рослин, що належать до 82 родів, 32 родин, поширені представники відділу Magnoliophyta (29 родин, 70 родів, 130 видів, 5 гібридів, один різновид). Серед листяних видів деревних рослин велика кількість видів належить до родини Rosaceae Juss. 26,0 \%, серед хвойних - до родини Pinaceae Lindl. $10,8 \%$.

Найбільше дендрорізноманіття представлено у двох КПП "Рокитнівський дендропарк" і "Сарненський дендропарк", відповідно 117 і 77 видів деревних рослин, 68 і 47 родів, 29 і 21 родин. У КПП "Рокитнівський дендропарк" зростає 74,5 \% деревних рослин, від загальної кількості у п'яти КПП.

Види деревних рослин п'яти КПП Українського Полісся належать до фанерофітів, 3 яких переважають листопадні дерева. За класами висоти переважають дерева першої величини (висота 25 і більше метрів) - 53 види.

Результати екологічного аналізу показують високу адаптивну здатність до кліматичних умов більшості інтродукованих видів деревних рослин.

Найбільш подібні дендрофлори між КПП "Рокитнівський дендропарк" i "Сарненський дендропарк" та КПП "Сарненський дендропарк" і "Більський дендропарк". Десять видів деревних рослин є спільними для всіх КПП.

\section{References}

1. Dzyba, A. A. (2020). Formation and transformation of man-made complex natural monuments from the second half of XX century in Ukrainian Polissia. Ukrainian Journal of Forest and Wood Science, 11(2), 66-78. https://doi.org/10.31548/forest2020.01.004

2. Dzyba, A. A., Rybchynska, N. P., \& Rybchynskyi, A. A. (2020). History of formation, taxonomic composition, biomorphological and ecological structure of the arboretum of Shatsk forest college named after V. V. Sulka. Ukrainian Journal of Forest and Wood Science, 11(3), 62-76. https://doi.org/10.31548/forest2020.03.007

3. Ismail, S. A., Pouteau, R., van Kleunen, M., Maurel, N., \& Kueffer, C. (2021). Horticultural plant use as a so - far neglected pillar of ex situ conservation. Conservation Letters, 1-8. https://doi.org/10.1111/conl.12825

4. IUCN 2021. The IUCN Red List of Threatened Species. Version 2020-3. Retrieved from: https://www.iucnredlist.org

5. Kalinichenko, O. A. (2003). Decorative dendrology. Kyiv: Higher School, 199 p. [In Ukrainian].

6. Kokhno, M. A., Hordiienko, V. I., Zakharenko, H. S., Kolesnichenko, O. M., Kuznetsov, S. I., Lohhinov, V. B., \& Chupryna, P. Y. (2001). The dendroflora of Ukraine. Wild and cultivated trees and shrubs. Gymnospermae. Kyiv: Higher school, 207 p. [In Ukrainian].

7. Kostina, N. V. (2013). Indexes of similarity and dissimilarity for territory zoning based on local floras. Bulletin of the Samara Scientific Center of the Russian Academy of Sciences, Vol. 15, 3(7), 2160-2168.

8. Kvach, I. (2019). Kivertsy National Nature Park "Tsumanska Pushcha" is a unique natural complex of Volyn Polissya. Nature Reserve area of Volyn Region: educational aspect: Regional Scientific and Practical Conference, Lutsk, October 10, 2019: conference materials. Lutsk, 40-43. [In Ukrainian].

9. Leontiev, D. V. (2008). Floristic analysis in mycology. Kharkiv: Basis, 160 p. [In Russian].

10. Litvinenko, S. G., \& Vykliuk, M. I. (2021). Autphytosozological evaluation of arboreous exotic plants of Pinophyta in the Yuriy Fedkovych Chernivtsi National University Botanical Garden. Scientific Bulletin of UNFU, 31(1), 30-36. https://doi.org/10.36930/40310105

11. Pokotylova, K. H. (2018). Ecological and geographical analysis of dendroflora of man-made reserve parks of Rivne region. Environmental sciences, 4(23), 134-139. [In Ukrainian].

12. Popovych, S. Yu., Savoskina, A. M., Sherstiuk, M. Yu., Mykhailovych, N. M., \& Dzyba, A. A. (2017). The reserved dendrososoflora of the Ukrainian Polissya. Kyiv: Ltd. "SP "Komprint"'".

13. Raunkiaer, C. (1934). The life forms of plants and statistical plant geography. Oxford: Clarendon Press, $632 \mathrm{p}$.

14. Sherstuk, M. Yu., \& Popovych, S. Y. (2019). Reserved dendrososophytes of Ukrainian Polissya: monograph. Kyiv: Ltd. "CP "Komprint"'", 272 p. [In Ukrainian].

15. State Committee of Construction, Architecture and Housing Policy of Ukraine. (2014). Instruction on inventory of green spaces in settlements of Ukraine. $18 \mathrm{p}$. Retrieved from: https://zakon.rada.gov.ua/laws/main/z0182-02

16. Tarasiuk, N., \& Polianskyi, S. (2019). Environmental risks of Volyn NPF in the conditions of climate change. Nature Reserve area of Volyn Region: educational aspect: Regional Scientific and Practical Conference, Lutsk, October 10, 2019, conference materials. Lutsk, 11-17. [In Ukrainian].

17. The concept of environmental education in Ukraine (2001). Retrieved from: https://zakon.rada.gov.ua/rada/show/v6-19290-01\#Text

18. The main directions of the state policy of Ukraine in the field of environmental protection, use of natural resources and provision of environmental safety. (1998). Retrieved from: https://zakon.rada.gov.ua/laws/show/188/98-vr\#Text

19. Tohtar, V. K., \& Fomina, O. V. (2011). Peculiarities of urbanoflora formation under different natural and anthropogenous conditions: factor analysis and visualization of data. Scientific statements, Series Natural Sciences, Vol. 15, 9(104), 23-39.

20. WFO. (2021). Word Flora Online Published on the Internet. Retrieved from: http://www.worldfloraonline.org/classification

21. Yakovlieva-Nosar, S. O., \& Bessonova, V. P. (2018). Dendroflora of the Shyroka Balka Ravine (Hortiza Island). Scientific Bulletin of UNFU, 28(2), 26-30. https://doi.org/10.15421/40280203

22. Zaiachuk, V. Y. (2005). Dendrology. Gymnospermae: Tutorial. Lviv: Ltd. "Firma Kamula", 175 p. [In Ukrainian]. 


\section{SYSTEMATIC, BIOMORPHOLOGICAL AND ECOLOGICAL STRUCTURES OF CURRENT DENROFLORA OF COMPLEX NATURAL MONUMENTS OF THE 1960S OF UKRAINIAN POLISSYA}

In the 1960s five complex natural monuments (CNM) of local significance were created in Ukrainian Polissya in the northern part of Rivne Region. The results of the inventory of the dendroflora in the SNM such as Tryputnyansky Park, Rokytnivskyi Dendropark, Sarnenskyi Dendropark, Vysotskyi Dendropark, and Bilskyi Dendropark are given. Our research has revealed that the systematic structure of the five SNMs is represented by 157 species, 5 hybrids, one variety belonging to 82 genera, and 32 families. The largest dendrodiversity is represented in SNM Rokytnivskyi Dendropark and Sarnenskyi Dendropark, by 117 and 77 species of woody plants belonging to 68 and 47 genera, 29 and 21 families respectively. At five SNMs, $70.3 \%$ of woody plant species belong to six IUCN Red List rarity categories, with LC and DD categories being the most widespread. Fraxinus pennsylvanica Marsh., which is under critical threat of extinction, belongs to the CR category at the two SNMs, namely in Sarnenskyi Dendropark and Vysotskyi Dendropark. The distribution of species by height showed the predominance of deciduous trees of the first magnitude predominate, of trees of the fourth magnitude, which consist of 33 and 27 species respectively, and of high and medium shrubs are represented by the same number of 24 species. Trees of the first magnitude predominate among coniferous species. 155 species of woody plants belong to phanerophytes, mega, meso and microphanerephytes are represented by almost the same number, which is 40,49 and 44 species, where deciduous trees predominate. The most widespread are mesophytes $-40.5 \%$ of the total number of species; the following groups are represented almost by the same number: mesohygrophytes and xeromesophytes (17.1 and $19.0 \%$, respectively). Representatives of hemioskyophytes ( 72 species) and heliophytes ( 63 species) became widespread due to the demand for lighting. In terms of demanding soil trophism, mesotrophs of 88 species $(55.7 \%)$ predominate on the territory of the SNM, slightly fewer oligotrophs 42 species $(26.6 \%), 26$ species $(16.5 \%)$ belong to megatrophs. To clarify the correlations between the studied floras of the five CNM, the Serensen-Chekanovskyi similarity coefficient was calculated; the maximum values were obtained for two pairs of dendrofloras of the SNM of Rokytnivskyi Arboretum and Sarnenskyi Dendropark and of the SNM of Sarnenskyi Dendropark and Bilskyi Dendropark, which indicates a significant level of similarity of dendrofloras.

Keywords: rare; woody plants species; similarity; representativeness; park. 